\title{
The Black Power Elites in The Age of Neoliberal Globalization
}

\author{
Paul C Mocombe* \\ Department of Philosophy and Sociology, West Virginia State University, USA
}

*Corresponding author: Paul C Mocombe, Department of Philosophy and

Received Date: February 11, 2020

Sociology, The Mocombeian Foundation, Inc, West Virginia State University, USA.

Published Date: March 04, 2020

\begin{abstract}
This article highlights the origins and constitution of the black power elites who would come to serve as the bearers of ideological and linguistic domination for black people the world-over in the age of neoliberal globalization. The work puts forth the argument that people of African descent in the age of neoliberal globalization are under the ideological and linguistic domination of two identities, the negro, i.e., black bourgeoisie, or African Americans, on the one hand, under the leadership of educated professionals and preachers; and the "my nigga," i.e., the black underclass, on the other hand, under the leadership of street and prison personalities, athletes, and entertainers vying for ideological and linguistic domination of black America. These two social class language games were historically constituted by different ideological apparatuses, the church and education on the one hand and the streets, prisons, and the athletic and entertainment industries on the other, of the global capitalist racial-class structure of inequality under American hegemony, which replaced the African ideological apparatuses of Vodou, peristyles, lakous, and agricultural production as found in Haiti. Contemporarily, given both groups' overrepresentation in the ideological superstructures of the American empire, they, antagonistically, have become the bearers of ideological and linguistic domination for all black youth the world-over.
\end{abstract}

Keywords: African americanization; Racial identity; Religiosity; Black diaspora; Spiritualism

\section{Introduction}

This article highlights the origins and constitution of the black power elites who would come to serve as the bearers of ideological and linguistic domination for black people the world-over in the age of neoliberal globalization under American hegemony. The work puts forth the argument that people of African descent in the age of neoliberal globalization are under the ideological and linguistic domination of two identities, the negro, i.e., black bourgeoisie, or African Americans, on the one hand, under the leadership of educated professionals and preachers; and the "my nigga," i.e., the black underclass, on the other hand, under the leadership of street and prison personalities, athletes, and entertainers vying for ideological and linguistic domination of black America. These two social class language games were historically constituted by different ideological apparatuses, the church and education on the one hand and the streets, prisons, and the athletic and entertainment industries on the other, of the global capitalist racial-class structure of inequality under American hegemony, which replaced the
African ideological apparatuses of Vodou, peristyles, lakous, and agricultural production as found in Haiti. Contemporarily, given their overrepresentation in the ideological superstructures of the American empire, the hegemon of the neoliberal (globalizing) world-system, the representatives of the aforementioned two social class language games, antagonistically, have become the bearers of ideological and linguistic domination for all black youth the worldover in the age of globalization.

\section{Background of the Problem}

Contemporarily, "culture of globalization" and the "globalization as culture" metaphors represent two sociological approaches to understanding the contemporary post-modern phenomenon we call globalization, the current configuration of the Protestant Ethic and the spirit of capitalism, under American hegemony (1970s-2000s). These two sociopolitical understandings regarding the origins and nature of globalization, as Kevin Archer et al (2007) points out, 
have "set off a vigorous and at times rancorous debate within the social sciences" (2007, pg. 2). On one side of the debate you have theorists who emphasize the "culture of globalization" and argue the idea that "the constitutive role of culture is critical for grasping the continued hegemony of capitalism in the form of globalization... Culture, they assert is increasingly being co-opted and deployed as a new accumulation strategy to broaden and deepen the frontiers of capitalism and to displace its inherent crisis tendencies" (Archer, 2007, pg. 2-3). In a word, in the continual hegemonic quest of capitalism to equalize the conditions of the world to serve capital, globalization, in the eyes of "culture of globalization" theorists, represents a stage of capitalism's development highlighted by the commodification of culture as a means for accumulating profits from the purchasing and consuming power of a transnational class of administrative bourgeoisies and professional cosmopolitan elites in core, semi-periphery, and periphery nation-states who subscribe to the social integrative norms of liberal bourgeois Protestantism (hard work, economic gain, political and economic liberalism, consumption, etc.).

In other words, the material and symbolic cultural elements of the cultures of the world are commodified by the upper class of owners and high-level executives of core countries-where finance capital and service jobs predominate-to make a profit or produce surplus-value-given the declining significance of profit from industrial production that have been shipped or outsourced to semi-periphery and periphery nations giving rise to their national bourgeoisies whose cultural practices and tastes have been nationalized-by fulfilling the consumption tastes of the financiers, administrative bourgeoisies, professional classes, and cosmopolitan elites of nation-states throughout the world who control their masses as a surplus labor force and cultural producers for global capital. Globalization, therefore, is the integration of the cultural realm and individual experiences into the commodity chains of the capitalist elites, who homogenize, through the media and other "ideological state apparatuses," the behavior and tastes of global social actors as consumers thereby homogenizing the cultural practices and tastes of the middle and under class peoples of the world in order to generate profit in postindustrial economies such as the US and UK.

This "culture-of-globalization" understanding of globalization or the postmodern condition in late capitalist development is a well-supported position, which highlights, in the twenty-first century, the continued hegemony of capitalism or capitalist relations of production in the form of globalization (Hardt and Negri, 2000; Kellner, 1988; Giddens, 1991; Harvey, 1989, 1990; Jameson, 1984, 1991). This line of thinking, in which theorists point to the underlining drive of globalization as the continuing historical push to socially, economically, and politically (under) develop the rest of the world along the lines, or as a simulacrum, of Western American and European Societies to facilitate capital accumulation, began with European colonialism, continued through the "development project" of the Cold-war era, and now is embodied in the globalization process. This historical process is highlighted in modernization, development, dependent development, worldsystems theories, and contemporarily it is a trend outlined in the theoretical works of postmodern theorists such as David Harvey and Fredric Jameson swho view globalization as postmodern or the cultural logic of capitalist development in core or developed countries. "Culture of globalization" theorists, such as Harvey and Jameson, therefore, view globalization as the new initiative, with the same intentions, replacing the accumulation and modernization project of colonialism and development with the consumerism of finance capital in core nations.

The sociocultural outcome of the colonial exploitative and oppressive socioeconomic military system was a racialized social structural relationship relationally constituted based on the "unequal" colonial division of labor and "unequal" ecological exchanges, which divided the social actors of the world between white, Christian, civilized, and "developed" European colonizers (masters) whose "burden" was to civilize and (under) develop the "undeveloped," "backward," non-European, colonized, colored, other, "heathens" (slaves) of the world. This European civilizing of the non-European colored "heathens" of the world initially took place through the Christian churches of the West, whose biblical tenets and metaphysics were used to justify the master/slave relationship of colonialism as well as teach its work ethic, which eventually homogenized the social actions of social actors to benefit the white male power elites of an emerging gendered, racialized, and religious global capitalist world-system that developed the white colonizer, while simultaneously under developing the colored colonized who were systematically forced to become agents of the Protestant ethic in agricultural production. A hybrid administrative bourgeoisie, and the poor seeking to be like them, emerged among the colonizers.

The end of the socioeconomic military colonial system in the form of decolonization in the twentieth century did not end the colonizer/colonized relational relationship, but gave rise to a new nation-state system of civilizing, domination, and exploitation within the hegemony of this emerging gendered, racialized, and religious global capitalism. Decolonization gave birth to what Philip McMichael calls, "the development project." According to McMichael, "[t]he mid-twentieth century development project (1940s-1970s), an internationally orchestrated program of national economic growth, with foreign financial, technological, and military assistance under the conditions of the Cold War, managed the aftermath of collapsing European and Japanese empires within the idealistic terms of the United nations and its focus on [national-state] governments implementing a human rightsbased social contract with their citizens...to equalize conditions across the world in laying the foundations of a global market that progressively overshadowed the states charged with development in the initial post-World War II era" [1]. Hence, the development project from the postcolonial era to the 1970s emphasized and continued the "unequal" colonial division of labor and "unequal" ecological exchanges within an Americentric dominated capitalist world-system subdivided into three geopolitical segments to benefit capitalist accumulation: the First World, the developed (postindustrial) capitalist Western countries plus Japan with America the model for development; the (industrial) Second World comprised of Communist Soviet blocs; and the (agricultural) Third World comprised of postcolonial bloc of nations. 
Whereas under colonialism, as McMichael notes, "[t]he basic pattern was to establish in the colonies specialized extraction and production of raw materials and primary products that were unavailable in Europe. In turn, these products fueled European manufacturing as industrial inputs and foodstuffs for its industrial labor force" (31), in the development phase of postcolonial capitalism, the process was reversed as the First World sought to take advantage of the desire of the postcolonial elites, the administrative bourgeoisie, of the Third World to develop their nation-states along the lines of the industrial First World. The basic global pattern was to establish in the emerging postcolonial "ThirdWorld" nation-states specialized manufacturing and industrial production sites that were outsourced from the First World. In turn, the outsourcing of these manufacturing and industrial jobs by the First World to take advantage of the urban underemployment and low-wage economy caused by the de-agriculturalization of Third World countries fueled First World, especially American, agribusinesses that channeled food surpluses, under a "food-aidregime," to Third World countries. "In agriculture, the Third World's share of world agricultural exports fell from 53 to 31 percent between 1950 and 1980, while the American granary consolidated its critical role in world agricultural trade. By the 1980s, the United States was producing 17 percent of the world's wheat, 63 percent of its corn, and 63 percent of its soybean; its share of world exports was 36 percent in wheat, 70 percent in corn, and 59 percent in soybeans"[1]. What developed from this global economic relationship was that Third World industrialization outlined by W.W. Rostow's stages of development fueled First world economic growth agriculturally and technologically, while under developing some Third World countries, and dependently developing others within the capitalist global world-system, hence recolonizing the Third World as they became indebted given their need to import food to feed their populous.

The postcolonial nations had no say in this new "unequal" development paradigm as "decisions about postcolonial political arrangements were made in London and Paris where the colonial powers, looking to sustain spheres of influence, insisted on the nation-state as the only appropriate political outcome of decolonization"[1]. Be that as it may, "[t]his new paradigm inscribed First World power and privilege in the new institutional structure of the postwar international economy. In the context of the Cold War between First and Second Worlds (for the hearts and resources of the ex-colonial world), "development" was simultaneously the restoration of a capitalist world market to sustain First World wealth, through access to strategic natural resources, and the opportunity for Third World countries to emulate First World civilization and living standards"[1]. The "development project," in this way, as McMichael further observed, continued the hegemony of capitalism, which started with colonialism, through the universalization of a global market system driven by the nation-state and economic growth through agricultural and industrial productions (2008, pg. 46). Globalization (1970s-2000s) is a continuation of this hegemonic capitalist process in a postcommunist world under the guidelines of neoliberalism.

Neoliberal globalization under American capitalist hegemony seeks to dismantle the state-centered exploitation of colonial and development capitalism via the invisible hand of economic (neo) liberalism, deregulation, privatization, education, class division, and social relations of global production. "The globalization project (1970s-2000s)," as McMichael observes, "liberalizing trade and investment rules, and privatizing public goods and services, has privileged corporate rights over the social contract and redefined development as a private undertaking" (2008, pg. 21). That is to say, in reestablishing a global capitalist economy through the development project that followed colonialism, the First World was able to indebt Third World countries through an exportoriented industrialization that fueled the wealth of First World agribusinesses, transnational corporations, and their citizens who became consumers of inexpensive manufactured goods from the Third World. Hence, "export-oriented industrialization fueled rapid economic growth, legitimizing a new 'free market' model of development, and in the 1980s this was represented as the solution to the debt crisis [of Third World countries]. Development, which had been defined as nationally managed economic growth, was redefined in the World Bank's World Development Report 1980 as 'participation in the world market"' [1].This global market is controlled and directed by multinational and transnational corporations operating in First World postindustrial cities where high finance banking jobs and low-end service jobs predominate over manufacturing and industrial jobs that have been outsourced to semi-periphery or developing nations. What has developed in turn is a continuation of the tripartite system of the development phase. In the globalization phase, however, what has developed is a tripartite system in which the global economic system parallels Immanuel Wallerstein's world-systems conception: a periphery group of poor nations whose comparative advantage are raw materials, agricultural production, and tourism; a semi-periphery group of industrial based nations, i.e., India, Mexico, Brazil, South Africa, Russia, and China; and a postindustrial group of core or developed nations led by the United States of America who generate profit by servicing the cultural consumptive needs of a multicultural and multiethnic transnational capitalist class who control and monitor their (US and other core countries) investments in periphery and semi-periphery nations.

In other words, the contemporary (1970 to the present) post-industrial mode of production in developed (core) states like the US is no longer characterized or driven by the industrial means for accumulating capital, which dominated the social relations of production of the last one hundred years in core or developed nations. Instead, the present globalization condition is driven-by, post-industrialism (consumerism)-the new means for accumulating capital-, and in such "developed" societies like the U.S., is characterized not by the industrial organization of labor, which have been outsourced overseas, but rather by capitalist finance and service occupations catering to the consumerist demands of a dwindling (transnational, transcultural, transracial, etc.) middle class the world over. In short, the rate of economic gain for its own sake or profit has fallen in industrial production due to labor laws (products of the welfare state) and ecological cost in developed countries like the US; hence the practice now among investors operating out of the US and other developed nations is on financial expansion "in which 'over-accumulated' capital switches from 
investments in production and trade, to investments in finance, property titles, and other claims on future income" (Trichur, 2005, pg. 165).

On a global scale, the bifurcation defining this current conjuncture is characterized on the one hand by an expansion of industrial production into some (others remain agricultural producers) developing or periphery countries, i.e., the semiperiphery, where the rate of labor exploitation has risen given their lack of environmental and labor laws, devalued labor, and the dismantling of the welfare state; and on the other hand, consumerism of cheaply produced goods and high-end service occupations have come to dominate developed and developing societies as capital in the developed world seeks to allow and incorporate, through the commodification of their cultural (sexual, gender, etc.) identities, the transnational class of elite "others" who administer the assets of capital into their consumption patterns.

"Globalization-as-culture" theorists out rightly reject this socioeconomic position or interpretation underlying the processes of globalization. They believe "that globalization is marked by the hollowing out of national cultural spaces either consequent upon the retrenchment of the nation state or because culture continues to be a relatively autonomous sphere" (Archer et al, 2007, pg. 2). That is, "[f]or the "globalization-as-culture" group...culture is not that easily enjoined due to its inherent counter-hegemonic properties vis-à-vis neo-liberal globalization. Rather, for this group..., contemporary globalization is not merely economic, but a system of multiple cultural articulations which are shaped by disjunctive space-time coordinates. In other words, globalization is as much if not more the product of inexorable and accelerated migratory cultural flows and electronic mass mediations beyond the space-time envelopes of the nation-state system and the successive socio-spatial fixes of global capitalism" (Archer et al, 2007, pg. 4). In fact, culture, in many instances, serves as a counter-hegemonic movement to (neo) liberal capitalism as a governing "rational" system. This line of thinking is best exemplified in the works of Stuart Hall (1992), John Tomlinson (1999), Homi Bhabha (1994), and Edward Said (1993) among many (postcolonial) others. For these theorists cultural exchanges are never one-dimensional, and hybridization of culture in many instances serves as a counterhegemonic force to the homogenization processes of global capital.

Theoretically, this debate between the advocates of the "globalization-as-culture" and the "culture-of-globalization" hypotheses is a fruitless debate grounded in a false ontological and epistemological understanding regarding the origins and nature of the (neo) liberal capitalist system that gives rise to the processes of globalization. Both groups ontologically and epistemologically assume that the origins of capitalism and its discursive practice is grounded in reason and rationality, thus drawing on the liberal distinction between capitalism as a public and neutral system of rationality that stands apart from the understanding of it as a private sphere or lifeworld cultural form grounded in the social ontology of the Protestant ethic as argued by Max Weber. The latter position, if assumed by both schools, is a point of convergence that resolves their opposition, and gives a better understanding of the origins and nature of the processes of globalization and counter movements to what are in fact metaphysical cultural forces/social class language games.

Both schools of thought are putting forth the same convergence argument, the culture of globalization position from a Marxian systems integration perspective and the globalization as culture position from a Weberian social integration perspective. For the culture of globalization position cultural practices are homogenized to be integrated within the rational rules or systemicity/social class language game of capitalist relations of production and consumption at the world-system level so as to generate surplusvalue from the consumption of cultural products as commodities in core postindustrial nations, industrial production in semi-periphery nations, and agricultural production in periphery nations.

The globalization as cultural group suggests that in the process of acculturating social actors to the organization of work within the capitalist world-system, homogenization does not take place. Instead, in the process of integration within the world-system, cultural groups intersubjectively defer meaning in ego-centered communicative discourse to hybridize the lexicons of significations coming out the globalization process thereby maintaining their cultural forms not in a commodified form but as a class-for-itself seeking to partake in the global community as hybrid social actors governed by the liberal rational logic of the marketplace.

The two positions are not mutually exclusive, however. For me, globalization, contemporarily, represents the homogenization of social discourse and action via hybridization. That is globalization represents the discursive practice, "spirit of capitalism," social class language game of agents of the Protestant Ethic seeking to allow for and homogenize "other" human behaviors, cultures, around the globe within the logic of their metaphysical discourse, "The Protestant Ethic and the spirit of capitalism social class language game," so as to accumulate profit, via agricultural, industrial, and post-industrial/consumerist production, for the predestined from the damned on a global scale. That is, via neoliberal globalization social actors around the globe are interpellated and socialized or embourgeoised via ideological apparatuses, churches, education, prisons, class division, and social relations of production, to become agents of the Protestant ethic so as to fulfill their labor and consumption roles in the organization of work, agricultural, industrial, or postindustrial production, required by their states in the global capitalist world-system under American hegemony since World War II. Proper socialization in the contemporary capitalist American dominated world-system is tantamount to hybridization, i.e., a liberal bourgeois Protestant other working for those who own, via the privatization of everything, the means and forces of production so as they themselves can become bourgeois as profit trickles down from capital operating in the first world or developed countries to the rest of the world, in order to consume the cultural and individual products found in postindustrial worldcities throughout the globe. Hence, hybridization of other cultures, via the homogenization process of globalization, is a simulacrum of white agents of the Protestant ethic, which enables the latter (whites) to make social actors of other cultures known for two reasons, to socialize them to the work ethic of the globalizing process and to accumulate surplus-value as the former service the 
others of their community for what has become since the 1960s a multicultural, multisexual, multiracial, etc., global capitalist worldsystem dominated by whites and hybrid others seeking equality of opportunity, recognition, and distribution with their white counterparts. The créolité, hybridity, ambivalence, etc., language of postmodern, post-structural, and postcolonial discourses represents the concepts, pathologies, etc., of the once-discriminated against "other" as they seek equality of opportunity, recognition, and distribution with their former slavemasters and colonizers by recursively reorganizing and reproducing their ideas and ideals as an "other."

In other words, on the one hand, neoliberal globalization represents the right-wing attempt to homogenize (converge) the nations of the globe into the overall market-orientation, i.e., private property, individual liberties, and entrepreneurial freedoms, of the capitalist world-system. This neoliberalization is usually juxtaposed, on the other hand, against the narcissistic exploration of self, sexuality, and identity of the left, which converges with the neoliberalizing process via the diversified consumerism of the latter groups as they seek equality of opportunity, recognition, and distribution with agents of the former within their market logic. Hence private property, individual liberties, diversified consumerism, and the entrepreneurial freedoms of the socalled marketplace become the mechanism of system and social integration for both groups although the logic of the marketplace is exploitative and environmentally hazardous. The black American power elites would emerge within this structure of the neoliberal global framework as structurally differentiated "other" agents of the Protestant Ethic and the spirit of capitalism seeking equality of opportunity, recognition, and distribution with their white counterparts.

\section{Black Practical Consciousnesses}

Since the 1960s, there have been two schools of thought on understanding the origins and nature of black American practical consciousnesses, the ideas black Americans recursively reorganize and reproduce in their material practices in the United States (US): the pathological-pathogenic and adaptive-vitality schools. The pathological-pathogenic position suggests that in its divergences from white American norms and values black American practical consciousness is nothing more than a pathological form of, and reaction to, American consciousness rather than a dual (both African and American) hegemonic opposing "identity-in-differential" (the term is Gayatri Spivak's) to the American one Elkins [2-11]. Afrocentric Proponents of the adaptive-vitality school suggest that the divergences are not pathologies but African "institutional transformations" preserved on the American landscape [12-27].

Contemporarily, both positions have been criticized for either their structural determinism as in the case of the pathologicalpathogenic approach, or racial/cultural determinism as in the case of the adaptive-vitality Kareng [22]. In directly or indirectly refuting these two positions for their structural and racial/cultural determinism, contemporary post-sixties and post-segregation era black scholars (Critical Race Theorists) in the United States (US) attempt to understand black consciousnesses and communities by using post-structural and post-modern theories to either reinterpret W.E.B. Du Bois's (1903) double consciousness construct as an epistemological mode of critical inquiry that characterizes the nature or essence of black consciousness, a la Cornel West (1993) and Paul Gilroy[19], or, building on the social constructivist work of Frantz Fanon, offer an intersectional approach to the constitution of black consciousnesses and communities, which emphasizes the diverse and different levels of alienation, marginalization, and domination, class, race, gender, global location, age, and sexual identity, by which black consciousnesses and communities get constituted, a la bell hooks (1993) and Patricia Hill Collins (1990) [28]. In spite of their efforts, these two dominant contemporary responses to the pathological-pathogenic and adaptivevitality positions inadequately resolve the structural and racial determinism of the aforementioned approaches by neglecting the fact that their theories and they themselves, like the positions of the pathological-pathogenic and adaptive-vitality schools, derive from the racial-class division and social relations of production of global capitalism or the contemporary Protestant capitalist world-system.

\section{Theory and Method}

Mystructural Marxistposition, phenomenological structuralism, building on the theoretical work of Louis Althusser [29], suggests that the rhetoric of pathological-pathogenic, adaptive-vitality, double-consciousness, intersectionality, postmodernism, and poststructuralism should be understood within and as being constituted by the dialectical structure of a global Protestant capitalist social structure of class inequality and differentiation put in place, through bodies, mode of production, language, ideology, and ideological state and transnational apparatuses, in order to limit, direct, and integrate the meaning and discursive practices of subjective identities, which may arise as a result of the decentered subject and the indeterminacy of meaning in ego-centered communicative discourse. Hence for me to understand the historical constitution of the aforementioned theories and the practical consciousnesses of black communities throughout the world, we must attempt to synthesize the rhetoric and black consciousness within structural Marxist dialectics, which highlights the class division and capitalist social structure of inequality put in place, through bodies, mode of production, language, ideology, ideological state and transnational apparatuses, and communicative discourse, to limit the practices of the indeterminate meanings and subjective positions allowed to organize and reproduce in a structural world organized since the sixteenth century for capital accumulation and class differentiation.

\section{Discussion and Conclusion}

Black American social agency occurred within the dialectic of the American Protestant capitalist social structure of racial-class inequality. No African ideological apparatuses were put in place to reorganize and reproduce an African worldview on the American landscape. The African body, which embodied its initial African practical consciousnesses that were reified in Africa, were thrown in, interpellated by, and socialized (embourgeoised) in new "white" capitalist ideological apparatuses that they would subsequently adopt and reproduce, i.e., the black church, nuclear family, etc., in regards to the politics of their black bodies not an African worldview. 
That is, their social agency centered on their identification as members of the society who recursively reproduced its ideas and ideals as people with black skin not as Africans with a distinct worldview (praxis, language, ideology, ideological apparatuses, and modes of production), represented in the discourse of whites as backwards and primitive, which they warred against, from that of their former slavemasters and colonizers.

As such, American blacks, as interpellated (workers) and embourgeoised agents of the American dominated global capitalist social structure of inequality, represent the most modern (i.e. embourgeoised) people of color, in terms of their "practical consciousness," in this process of homogenizing social actors as agents of the protestant ethic or disciplined workers working for owners of production in order to obtain economic gain, status, and upward mobility in the larger American society and the world. Whereas, they once occupied the social space as agricultural and industrial workers, the former less educated than the latter, which were much wealthier because of their education and industrial work and therefore made education and industry the means to economic gain and upward economic mobility. Today, they continue to constitute the social space and their practical consciousness in terms of their relation to the means of production in post-industrial capitalist America. This relation differentiates black America for the most part into two status groups, a dwindling middle and upper class (living in suburbia) that numbers about 25 percent of their population (13 percent) and obtain their status as preachers, doctors, athletes, entertainers, lawyers, teachers, and other highend professional service occupations; and a growing segregated "black underclass" of criminals, unemployed, and under-employed wage-earners occupying poor inner-city communities and schools focused solely on technical skills, multicultural education, athletics, and test-taking for social promotion given the relocation of industrial and manufacturing jobs to poor periphery and semiperiphery countries and the introduction of low-end post-industrial service jobs and a growing informal economy in American urbancities [30]. Whereas street and prison personalities, rappers, athletes, and entertainers, many of whom refer to themselves and their compatriots as "my niggas," are the bearers of ideological and linguistic domination for the latter; the former, once called negroes, the black bourgeoisie (E. Franklin Frazier's term), and now AfricanAmericans, is predominantly influenced by preachers and educated professionals as the bearers of ideological and linguistic domination. Both groups share the same ideals and goals, i.e., economic gain, status, and upward social mobility, within the class division and social relations of production of the Protestant capitalist worldsystem under American hegemony. Therefore, their practical consciousness is neither progressive, nor counterhegemonic. It is reproductive.

However, America's transition to a postindustrial, financialized service, economy beginning in the 1970s, decentered the negro (black bourgeoisie/African American) practical consciousness, and reified and positioned black American "my nigga" underclass ideology and language, hip-hop culture, as a viable means for black American youth to identify with and achieve economic gain, status, and upward economic mobility in the society over education and succeeding academically as emphasized by black bourgeois discourse. Finance capital in the US beginning in the 1970s began investing in entertainment and other service industries where the inner-city language, street, prison, entertainment, and athletic youth culture of black America became both a commodity and the means to economic gain for the black poor in America's postindustrial economy, which subsequently outsourced its industrial work to semi-periphery nations thereby blighting the inner-city communities. Blacks, many of whom migrated to the northern cities from the agricultural south looking for industrial work in the north following the Civil War (1861-1865), became concentrated in blighted communities where work began to disappear, schools were underfunded, and poverty increased. The black migrants, which migrated North with their Black/African-American English Vernacular (BEV/AAEV) from the agricultural South, became segregated sociolinguistic underclass communities, ghettoes, of unemployed laborers looking to illegal, athletic, and entertainment activities (running numbers, pimping, prostitution, drug dealing, robbing, participating in sports, music, etc.) for economic success, status, and upward mobility. Educated in the poorly funded schools of the urban ghettoes, given the process of deindustrialization and the flight of capital to the suburbs, with no work prospects, many black Americans became part of a permanent, BEV/AAEV speaking and poorly educated underclass looking to other activities for economic gain, status, and upward economic mobility. Those who were educated became a part of the social class language game of the Standard-English-speaking black middle class of professionals, i.e., preachers, teachers, doctors, lawyers, etc. (the black bourgeoisie), living in the suburbs, while the uneducated or poorly educated constituted the social class language game of the black underclass of the urban ghettoes where the streets, prisons, athletics, and the entertainment industries became the ideological apparatuses for their socialization. Beginning in the late 1980s, finance capital began commodifying and distributing (via the media industrial complex) the social class language game of the underclass black culture for entertainment in the emerging postindustrial economy of the US over the ideology and language, social class language game, of the black bourgeoisie. Be that as it may, efforts to succeed academically among black Americans, which constituted the ideology and language of the black bourgeoisie, paled in comparison to their efforts to succeed as speakers of Black English, athletes, "gangstas", "playas", and entertainers, which became the ideology and language of the black underclass living in the inner-cities of America. Authentic black American identity became synonymous with black underclass hip-hop ideology and language represented by young athletes and entertainers, LeBron James, Derek Rose, Lil ' Wayne, Jay-Z, Kanye West, Tupac Shakur, Biggie Smalls, etc., over the social class language game of the educated black professional class under the ideological and linguistic domination of black preachers, TD Jakes, Creflo Dollar, Jamal Bryant, Juanita Bynum, etc., and other educated black professionals.

The black underclass in America's ghettoes has slowly become, since the 1980s, with the financialization of hip-hop culture as an art form and entertainment by record labels such as Sony and others, athletics, and the entertainment industry, the bearers of ideological and linguistic domination for the black youth community in America. Their language and worldview as constituted through the 
streets, prisons, hip-hop culture, athletics and the entertainment industry financed by finance capital, has become the means by which black youth (and youth throughout the world) attempt to recursively reorganize and reproduce their material resource framework against the purposive-rationality of educated black bourgeois or middle class America. The upper-class of owners and high-level executives of the American dominated capitalist worldsystem have capitalized on this through the commodification of black "my nigga" underclass culture, which mainstreamed it. This is further supported by an American media and popular culture that glorifies the streets, athletes, entertainers, and the "Bling bling," wealth, diamonds, cars, jewelry, and money. Hence the aim of many young blacks in the society is no longer to seek status, economic gain, and upward mobility through a Protestant Ethic that stresses hard work, diligence, differed gratification, and education; on the contrary, the Protestant ethic in sports, music, instant gratification, illegal activities (drug dealing), and skimming are the dominant means portrayed for their efforts through the entertainment industry financed by post-industrial capital. Schools throughout urban inner cities are no longer seen as means to a professional end in order to obtain economic gain, status, and upward mobility, but obstacles to that end because it delays gratification and is not correlative with the means associated with economic success and upward mobility in black urban America. More black American youth (especially the black male) want to become, football and basketball players, rappers and entertainers, like many of their role models, LeBron James, Derek Rose, Lil ' Wayne, Jay-Z, Kanye West, Tupac Shakur, Biggie Smalls, etc., who were raised in their urban underclass environments and obtained economic gain and upward mobility that way, over doctors, lawyers, engineers, etc., the social functions associated with the status symbol of the black and white middle class (negroes) of the civil rights generation. Hence the end and social action of the larger society remains the same, economic success, status, and upward economic mobility, only the means to that end have shifted with the rise, financed by finance capital, of the black underclass as the bearers of ideological and linguistic domination in black America given the commodification of hiphop culture and their high visibility in the media and charitable works through basketball and football camps and rap concerts, which reinforce the aforementioned activities as viable professions (means) to wealth and status in the society's postindustrial economy, which focuses on services and entertainment for the world's transnational bourgeois class as the mode of producing surplus-value.

This linguistic and ideological domination and the ends of the power elites (rappers, athletes, gangsters) of the black underclass are juxtaposed against the Protestant Ethic and spirit of capitalism of the educated black middle and upper middles classes represented in the discourse and discursive practices of black American prosperity preachers in the likes of TD Jakes, Creflo Dollar, Jamal Bryant, Juanita Bynum, Eddie Long, etc. who push forth, via the black American church, education and professional jobs as the more viable means to economic gain, status, and upward economic mobility in the society over the street life of the urban ghettoes. Hence, whereas, for agents of the Protestant Ethic in the likes of Jakes, Dollar, Bryant, Bynum, and Long the means to "Bling bling," or the American Dream, is through education, obtaining a professional job, and material wealth as a sign of God's grace, salvation, and blessings. Rapping, hustling, sports, etc., for younger black Americans growing up in innercities throughout the US, where industrial work has disappeared, represent the means (not education) to the status position of "Bling bling."

Hence what I am suggesting here is that, contemporarily, black American youth are not "acting white" (John Ogbu's term) when education no longer becomes a priority or the means to economic gain, status, and upward mobility, as they get older and consistently underachieve vis-à-vis whites; they are attempting to be white and achieve bourgeois economic status (the "Bling bling" of cars, diamonds, gold, helicopters, money, etc.) in the society by being "black," speaking Ebonics, rapping, playing sports, hustling, etc., in a racialized post-industrial capitalist social structure wherein the economic status of "blackness" is (over) determined by the white and black capitalists class of owners and high-level executives and the black proletariats of the West, the black underclass, "my nigga," whose way of life and image ("athletes, hustlers, hip-hopsters") has been reified, commodified (by white and black capitalists), and distributed throughout the world for entertainment, (black) status, and economic purposes in post-industrial capitalist America. This "my nigga" underclass culture as globally promulgated throughout the black diaspora by finance capital via Black Entertainment Television (BET) and other media outlets is counterbalanced or opposed by "the negro" (black bourgeois/African American) black preachers and educated professionals promoting the same ethos, The Protestant Ethic and the spirit of capitalism, via black American churches and televangelisms, to other blacks around the world via biblical conversion or salvation, over the pathologies of the black American ("my nigga") underclass, as the medium to and for success in the Protestant capitalist worldsystem. Hence, the social structure of class (not racial or cultural worldview) inequality that characterizes the black American social environment is subsequently the relational framework, which black youth in the diaspora are exposed to and socialized in when they encounter globalizing processes under American hegemony through immigration, the outsourcing of work from America, and the images of the entertainment industry Wilson, [31,32].

Throughout the continent of Africa, the Caribbean, and black Europe black American charismatic preachers are promoting a prosperity gospel among the black poor, which is usually juxtaposed against the emergence of a "my nigga" underclass culture among the youth in these areas influenced by the hip-hop, street, prison, athletic, and music culture of the black American underclass [32]. Nigerian, South African, East African, St. Lucian, Jamaican, Haitian, and black British Caribbean Hip-Hop, gangsta rap music, Bling bling, dress code, etc., influenced by the black American underclass are juxtaposed against the Protestant evangelism of Nigerian, South African, East African, St. Lucian, Jamaican, Haitian, and black British Caribbean preachers influenced by TD Jakes, Creflo Dollar, Juanita Bynum, and other black charismatic preachers whose global outreach throughout the diaspora are converting other blacks to agents of the Protestant Ethic and the spirit of capitalism. These two racial-class identities, whose practices are 
reified in postindustrial America, the hegemon of globalization, represent the class dynamics within which black others throughout the world are dialectically integrated into the capitalist worldsystem. Future research in the likes of Mwenda [32-50], who looks at the emergence of East African Hip Hop (Kenya, Uganda, and Tanzania) in his work East African Hip Hop, must continue to explore the aforementioned African American class dynamics, led by black American athletes, entertainers, hip hopsters and preachers as the bearers of ideological and linguistic domination, by which other blacks throughout the world are integrated into the capitalist world-system under American hegemony [51-100]. Albeit Ntarangwi, in contradistinction to my position, views the African-Americanization of African youth not as a form of cultural imperialism, but as an authentic voice for African youth to contest power and oppression. I, unfortunately, view both the Negro and "my nigga" images as the death of the African and the emergence of "black-skinned, white masked" (Frantz Fanon's term) agents of the Protestant Ethic and the spirit of capitalism [101-122].

\section{Acknowledgement}

None.

\section{Conflicts of Interest}

No Conflicts of Interest.

\section{References}

1. Mc Michael Philip (2008) Development and Social Change: A Global Perspective. Sage Publications, California, USA.

2. Frazier Franklin E (1939) The Negro Family in America. University of Chicago Press, Chicago, USA.

3. Frazier Franklin E (1957) Black Bourgeoisie: The Rise of a New Middle Class. The Free Press, New York, USA.

4. Genovese Eugene (1974) Roll, Jordan, Roll. Pantheon Books, New York, USA.

5. Murray Charles (1984) Losing Ground: American Social Policy. New York, USA.

6. Moynihan Daniel P (1965) The Negro Family. Washington, USA.

7. Myrdal Gunnar (1944) An American Dilemma: The Negro Problem and Modern Democracy. Harper \& Row Publishers, New York, USA.

8. Wilson William J (1978) The Declining Significance of Race: Blacks and Changing American Institutions. The University of Chicago Press, USA.

9. Wilson William J (1987) The Truly Disadvantaged. University of Chicago Press, USA.

10. Sowell Thomas (1975) Race and Economics. New York, USA.

11. Sowell Thomas (1981) Ethnic America. New York, USA.

12. Allen Richard L (2001) The Concept of Self: A Study of Black Identity and Self Esteem. Detroit: Wayne State University Press, USA.

13. Asante Molefi Kete (1988) Afrocentricity. New Jersey, USA.

14. Asante Molefi K (1990a) Kemet Afocentricity and Knowledge. New Jersey, USA.

15. Billingsley Andrew (1968) Black Families in White America. New Jersey, USA.

16. Billingsley Andrew (1970) Black Families and White Social Science. Journal of Social Issues 26:127-142.
17. Billingsley Andrew (1993) Climbing Jacob's Ladder: The Enduring Legacy of African American Families. New York, USA.

18. Blassingame John W (1972) The Slave Community: Plantation Life in the Antebellum South. New York: Oxford University Press, USA.

19. Gilroy Paul (1993) The Black Atlantic: Modernity and Double Consciousness. Cambridge, UK.

20. Gutman Herbert (1976) The Black Family in Slavery and Freedom. Pantheon Books, New York, USA. PP. 1750-1925.

21. Holloway Joseph E (1990a) Africanisms in American Culture. Indiana University Press, USA.

22. Karenga Maulana (1993) Introduction to Black Studies. The University of Sankore Press, California, USA.

23. Levine Lawrence W (1977) Black Culture and Black Consciousness: Afro-American Folk Thought from Slavery to Freedom. Oxford University Press, New York, USA.

24. Lincoln Eric C, Lawrence H Mamiya (1990) The Black Church in the African American Experience. Duke University Press, London, UK.

25. Nobles Wade (1987) African American Families: Issues, Ideas and Insights. Black Family Institute, California, USA.

26. Staples Robert (1978) The Black Family: Essays and Studies. California, USA.

27. Stack Carol B (1974) All Our Kin: Strategies for Survival in a Black Community. Harper \& Row Publishers, New York, USA.

28. Reed Adolph L (1997) Du Bois and American Political Thought: Fabianism and the Color Line. Oxford University Press, New York, USA.

29. Althusser Louis (2001) Lenin and Philosophy and Other Essays. New York: Monthly Review Press, USA.

30. Sennett Richard (1998) The Corrosion of Character. New York, USA.

31. Watkins S Craig (1998) Representing: Hip-Hop Culture and the Production of Black Cinema. The University of Chicago Press, USA.

32. Ntarangwi Mwenda (2009) East African Hip Hop: Youth Culture and Globalization. University of Illinois Press, Chicago, USA.

33. Althusser Louis, Étienne Balbi (1970) Reading Capital. London, UK.

34. Balibar Etienne, Immanuel Wallerstein (1991) Race, Nation, Class: Ambiguous Identities. London, UK.

35. Bell Daniel (1985) The Social Sciences Since the Second World War. New Brunswick, Fredericton.

36. Boskin Joseph (1965) Race Relations in Seventeenth-Century America: The Problem of the Origins of Negro Slavery. In: Donald Noel (Ed.), The Origins of American Slavery and Racism pp. 95-105.

37. Charles E. Merrill (1990) The Logic of Practice. California, USA.

38. Bourdieu Pierre (1984) Distinction: A Social Critique of the Judgement of Taste. Cambridge, UK.

39. Brecher Jeremy, Tim Costello (1998) Global Village or Global Pillage. Reconstruction from the bottom up. Mass: South End Press, Cambridge, UK.

40. Chase Dunn Christopher, Peter Grimes (1995) World-Systems Analysis. Annual Review of Sociology 21: 387-417.

41. Chase Dunn Christopher, Richard Rubinson (1977) Toward a Structural Perspective on the World-System. Politics Society 7(4): 453-476.

42. Chase Dunn Christopher (1975) The effects of international economic dependence on development and inequality: A cross-national study. American Sociological Review 40: 720-738.

43. Clarke, John Henrik (eds.) (1970) Black Titan: WEB Du Bois. Boston: Beacon Press, USA.

44. Cohen J (2002) Protestantism and Capitalism: The Mechanisms of Influ- 
ence. New York, USA.

45. Coser Lewis (1956) The functions of social conflict. New York: The Free Press, USA.

46. Crothers Charles (2003) Technical Advances in General Sociological Theory: The Potential Contribution of Post-Structurationist Sociology. Perspectives 26(3): 3-6.

47. Dahrendorf Ralf (1959) Class and Class Conflict in Industrial Society. Stanford University Press, California, USA.

48. Douglas M (1986) How Institutions Think. Syracuse University Press, New York, USA.

49. Drake St Claire (1965) The Social and Economic Status of the Negro in the United States. In: Talcott Parsons and Kenneth B. Clark (Eds.), The Negro American Boston, USA pp. 3-46.

50. Du Bois W (1995) The Souls of Black Folk. Penguin Putnam Inc New York, USA.

51. Fanon Frantz (1967) Black Skin, White Masks. Grove Press, New York, USA.

52. Fanon Frantz (1963) The Wretched of the Earth. Grove Press, New York, USA.

53. Foucault Michel (1977) Discipline and Punish: The Birth of the Prison. Penguin Books, London, UK.

54. Franklin John Hope, Alfred A Moss Jr (2000) From Slavery to Freedom: A History of African Americans. New York, USA.

55. Fraser Nancy (1997) Justice Interruptus: Critical Reflections on the "Post socialist" Condition. New York, USA.

56. Frazier Franklin E (1968) The Free Negro Family. Arno Press and The New York Times, New York, USA.

57. Gadamer Hans Georg (2002) Truth and Method (Second, Revised Edition, Joel Weinsheimer and Donald G. Marshall, Trans.), New York, USA.

58. Gartman David (2002) Bourdieu's Theory of Cultural Change: Explication, Application, Critique. Sociological Theory 20 (2): 255-277.

59. Gates Henry Louis Jr, Cornel West (1996) The Future of the Race. Vintage Books, New York, USA.

60. Geronimus Arline, Phillip Thompson To Denigrate, Ignore, or Disrupt: Racial Inequality in Health and the Impact of a Policy induced Breakdown of African American Communities. Du Bois Review 1(2): 247-279.

61. Glazer Nathan, Daniel P Moynihan (1963) Beyond the Melting Pot. Cambridge, UK. Gramsci Antonio (1959) The Modern Prince, and Other Writings. International Publishers, New York, USA.

62. Gutiérrez Ramón A (2004) Internal Colonialism: An American Theory of Race. Du Bois Review 1(2): 281-295.

63. Habermas Jürgen (1987) The Theory of Communicative Action: Lifeworld and System: A Critique of Functionalist Reason Beacon Press, Boston, USA.

64. Habermas Jürgen (1984) The Theory of Communicative Action: Reason and the Rationalization of Society. Beacon Press, Boston USA.

65. Harding Vincent (1981) There is a River: The Black Struggle for Freedom in America. New York, USA.

66. Hare Nathan (1991) The Black Anglo-Saxons. Third World Press, Chicago, USA.

67. Harris Marvin (1999) Theories of culture in postmodern times. AltaMira Press, California, USA.

68. Harris David R, Jeremiah Joseph Sim (2002) Who is Multiracia Assessing the Complexity of Lived Race. American Sociological Review 67(4): 614-627.

69. Hogue Lawrence W (1996) Race, Modernity, Postmodernity: A look at the History and the Literatures of People of Color Since the 1960s. State University of New York Press, New York, USA.
70. Holloway Joseph E (1990b) The Origins of African American Culture. In: Joseph Holloway (Ed.), Africanisms in American Culture. Indiana University Press, USA, 19-33.

71. Horkheimer Max, Theodor W Adorno (2000) Dialectic of Enlightenment. New York, USA.

72. Horne Gerald (1986) Du Bois and the Afro-American Response to the Cold War. State University of New York Press. New York, USA.

73. Hudson Kenneth, Andrea Coukos (2005) The Dark Side of the Protestant Ethic: A Comparative Analysis of Welfare Reform. Sociological Theory 23(1): 1-24.

74. Jameson Fredric, Masao Miyoshi (1998) The Cultures of Globalization. Duke University Press, Durham, UK

75. Kardiner Abram, Lionel Ovesey (1962) The Mark of Oppression: Explorations in the Personality of the American Negro. Meridian Ed, USA

76. Kellner Douglas (2002) Theorizing Globalization. Sociological Theory 20(3): 285-305.

77. Kurtz Lester R (2007) Gods in the Global Village: The World's Religions in Sociological Perspective. Sage Publications, California, USA.

78. Lukács Georg (1971) History and Class Consciousness: Studies in Marxist Dialectics. The MIT Press, Cambridge, USA.

79. Lukács Georg (2000) A Defence of History and Class Consciousness: Tailism and the Dialectic. New York, USA.

80. Lyman Stanford M (1997) Postmodernism and a Sociology of the Absurd and Other Essays on the Nouvelle Vague in American Social Science. The University of Arkansas Press, North Carolina, USA.

81. Lyman Stanford M, Arthur J Vidich (1985) American Sociology: Worldly Rejections of Religion and Their Directions. Yale University Press, London, USA.

82. Lyman Stanford M (1972) The Black American in Sociological Thought. New York, USA.

83. Massey DS, Denton NA (1993) American Apartheid: Segregation and the Making of the Underclass. Harvard University Press, Cambridge, USA.

84. Marable Manning (1986) Du Bois: Black Radical Democrat. Twayne Publishers, Boston, USA.

85. Marcuse Herbert (1964) One-Dimensional Man. Beacon Press, Boston, USA.

86. Marcuse Herbert (1974) Eros and Civilization: A Philosophical Inquiry into Freud. Beacon Press, Boston, USA.

87. Marshall Gordon (1998) A Dictionary of Sociology. Oxford University Press, UK.

88. Marx Karl, Friedrich Engels (1964) The Communist Manifesto. Penguin Books, England, UK.

89. Marx Karl (1992) Capital: A Critique of Political Economy. International Publishers, New York, USA.

90. Marx Karl (1998) The German Ideology. Prometheus Books, New York, USA.

91. Mason Patrick L (1996) Race, Culture, and the Market. Journal of Black Studies 26(6): 782-808

92. Meier August (1963) Negro Thought in America 1880-1915: Racial Ideologies in the Age of Booker T Washington. The University of Michigan Press, Michigan, USA.

93. Meier August, Elliott M Rudwick (1976) From Plantation to Ghetto; an Interpretive History of American Negroes. New York, USA.

94. Mocombe Paul C (2004) Who Makes Race Matter in Post-Industrial Capitalist America. Race Gender Class 11(4): 30-47.

95. Mocombe Paul C (2005) Education in Globalization. University Press of America, Maryland, USA.

96. Mocombe Paul C (2009) The Soulless Souls of Black Folk: A Sociologi- 
cal Reconsideration of Black Consciousness as Du Boisian Double Consciousness. University Press of America, Maryland, USA.

97. Nash Gary B (1972) Red, White and Black: The Origins of Racism in Colonial America. In: Donald Noel (Ed.), The Origins of American Slavery and Racism. USA, pp. 131-152.

98. Ortner Sherry (1984) Theory in Anthropology Since the Sixties. Comparative Studies in Society and History 26: 126-66.

99. Patterson Orlando (1982) Slavery and Social Death: A Comparative Study. Harvard University Press, Cambridge, USA.

100. Phillips UB (1918) American Negro Slavery: A survey of the Supply, Employment, and Control of Negro Labor as Determined by the Plantation Regime. New York, USA.

101. Phillips UB (1963) Life and Labor in the Old South. Boston, USA.

102. Polanyi Karl (2001) The Great Transformation: The Political and Economic Origins of Our Time. Beacon Press, Boston, USA.

103. Rampersad Arnold (1976) The Art and Imagination of WEB Du Bois. Harvard University Press, Cambridge, USA.

104. Roediger David R (1999) The Wages of Whiteness: Race and the Making of the American Working Class. New York, USA.

105. Rose Sonya O (1997) Class Formation and the Quintessential Worker. In: John R. Hall (Ed.), Reworking Class. Cornell University Press, London, UK pp. 133-166

106. Rubin Vera (1960) Caribbean Studies: A Symposium. University of Washington Press, USA.

107. Sklair Leslie (1995) Sociology of the Global System. Westview Press, Maryland, USA.

108. Slemon Stephen (1995) The Scramble for Postcolonialism. In: Bill Ashcroft (Eds.), The Post-colonial Studies Reader. London, UK pp. 45-52.

109. Smiley Group Inc (2006) The Covenant with Black America. Third World Press, Chicago, USA.
110. Smith MG (1960) The African Heritage in the Caribbean. In: Vera Rubin (Ed.), Caribbean Studies: A Symposium. University of Washington Press, USA pp. 34-46

111. Stuckey Sterling (1987) Slave Culture: Nationalist Theory and the Foundations of Black America. Oxford University Press, USA.

112. Sudarkasa Niara (1980) African and Afro-American Family Structure: AComparison. The Black Scholar 11: 37-60.

113. Sudarkasa Niara (1981) Interpreting the African Heritage in Afro-American Family Organization. In: Harriette P McAdoo (Ed.), Black Families. Sage Publications, USA.

114. Sundquist Eric J (1996) The Oxford WEB Du Bois Reader. Oxford University Press, USA.

115. Wallerstein Immanuel (1982) The Rise and Future Demise of the World Capitalist System: Concepts for Comparative Analysis. In Hamza Alavi and Teodor Shanin (Eds.), Introduction to the Sociology of "Developing Societies". Monthly Review Press, USA pp. 29-53.

116. Ward Glenn (1997) Postmodernism. London, UK.

117. Weber Max (1958) The Protestant Ethic and the Spirit of Capitalism. New York: Charles Scribner's Sons. West, Cornel. New York, USA.

118. Wilson Kirt H (1999) Towards a Discursive Theory of Racial Identity: The Souls of Black Folk as a Response to Nineteenth Century Biological Determinism. Western Journal of Communication 63(2): 193-215.

119. Winant Howard (2001) The World is a Ghetto: Race and Democracy since World War II. New York, USA.

120. Wright Kai (2001) The African American Archive: The History of the Black Experience in Documents. Black Dog \& Leventhal Publishers, USA.

121. Woodson Carter G (1969) The Mis Education of the Negro. Associated Publishers Inc, USA.

122. Giddens Anthony (1984) The Constitution of Society: Outline of the Theory of Structuration. Polity Press, Cambridge, UK. 